КРАШЕНІНІН О. С., Д-р техн. наук, проф., ОДСГОВ М. М., старш. викл., БЕРЕЗНЯК М. К., магістр, ПИВОВАР Д. І., магістр (Український державний університет залізничного транспорту)

\title{
Пропозиції зі скорочення енерговитрат у локомотивному депо
}

Енергетичне господарство локомотивного депо займає суттєву частку витрат на організаџію функиіонування інших господарств депо і локомотивного парку. В умовах подорожчання иін на енергоресурси перед локомотивним господарством депо постають актуальні завдання розроблення комплексу заходів щзодо запровадження стратегії економії енерговитрат.

У статті аналізується динаміка технічного стану локомотивного парку і динаміка енерговитрат депо за кілька років. Зважаючи на цее, намічено конкретні пропозиції з економії енерговитрат у локомотивному депо.

Ключові слова: локомотивне господарство, енерговитрати, економія енерговитрат.

\section{Вступ}

Локомотивне господарство залізниць є значним споживачем паливно-енергетичних ресурсів. Витрати на енергоносії становлять значну частину у структурі експлуатаційних витрат Укрзалізниці, що доходять до $20 \%[1]$.

3 них більше $80 \%$ дизельного пального та $83 \%$ електроенергії витрачається локомотивами для забезпечення перевізного процесу [2].

Безумовно, саме це $\epsilon$ підставою вирішення завдання скорочення енерговитрат залізниці.

Однак загальна зношеність рухомого складу, в тому числі i локомотивного парку, обумовлює причини погіршення основних показників роботи залізничного транспорту i показників роботи локомотивного депо.

На законодавчому рівні розроблено напрями, що визначають стратегію запровадження енергозбереження і енергоефективності [3-5].

Усе це визначає актуальність заходів, що на рівні локомотивного господарства дають змогу заощаджувати і скорочувати витрати енергоресурсів.

\begin{tabular}{l}
\hline Аналіз останніх досліджень і публікацій \\
\hline Останніми роками з’явилося багато наукових \\
публікацій, що пов’язані з підвищенням ефективності і \\
скороченням витрат енергоресурсів на локомотивне \\
господарство. Їх можна розділити на дослідження в \\
галузі оптимізації руху поїздів [6-9], системи \\
випробувань [10, 11], проведення енергетичного \\
аудиту [12] та заощадження ринку електроенергії [13]. \\
Теоретичне обгрунтування вибору оптимальної \\
траєкторії руху поїзда виконується методами
\end{tabular}

оптимізації [14] та динамічного програмування [15], що сприяє економії енерговитрат на перевезення.

Разом 3 цим практика експлуатації локомотивів вносить корективи i доповнює теоретичні дослідження.

Так, людський фактор може суттєво впливати на заходи 3 енергозбереження: неякісне виконання ремонту, відсутність або несвоєчасна поставка запасних частин і матеріалів на ремонтні дільниці, брак досвіду i низька кваліфікація персоналу як у ремонті, так і в експлуатації локомотивів.

Крім того, вирішення глобальних завдань 3 економії енергоресурсів не може відокремлюватися від вирішення повсякденних, а саме: утеплення виробничих i iнших приміщень теплозахисними матеріалами, запровадження енергоощадного виробництва, використання альтернативних джерел енергії та ін.

\section{Визначення мети і завдання дослідження}

Стаття присвячена запровадженню пропозицій 3 економії енерговитрат у локомотивному господарстві 3 урахуванням аналізу показників роботи локомотивного депо.

Відповідно до поставленої мети необхідно вирішити такі завдання:

1. Проаналізувати динаміку показників роботи локомотивів у депо і витрат енергоресурсів.

2. Отримати математичні залежності для визначення і прогнозування можливих змін динаміки показників роботи локомотивів i витрат енергоресурсів.

() О. С. Крашенінін, М. М. Одєгов, М. К. Березняк, Д. І. Пивовар, 2021 
3. На основі енерговитрат депо розробити комплекс заходів і пропозицій з енергозбереження в усіх підрозділах локомотивного депо.

\section{Основна частина дослідження}

За період 32016 по 2019 рік за даними локомотивного депо К проаналізовано динаміку кількісних і якісних показників роботи локомотивів.
На підставі цих даних побудовано графічні залежності динаміки змін цих показників роботи депо за чотири роки (рис. 1-12). Аналіз цієї динаміки дає змогу робити певні висновки.

Незважаючи на складні економічні і політичні обставини, обсяг перевезень мав достатньо стабільний характер і навіть зростав, але значно відрізнявся від запланованих показників (рис. 1).

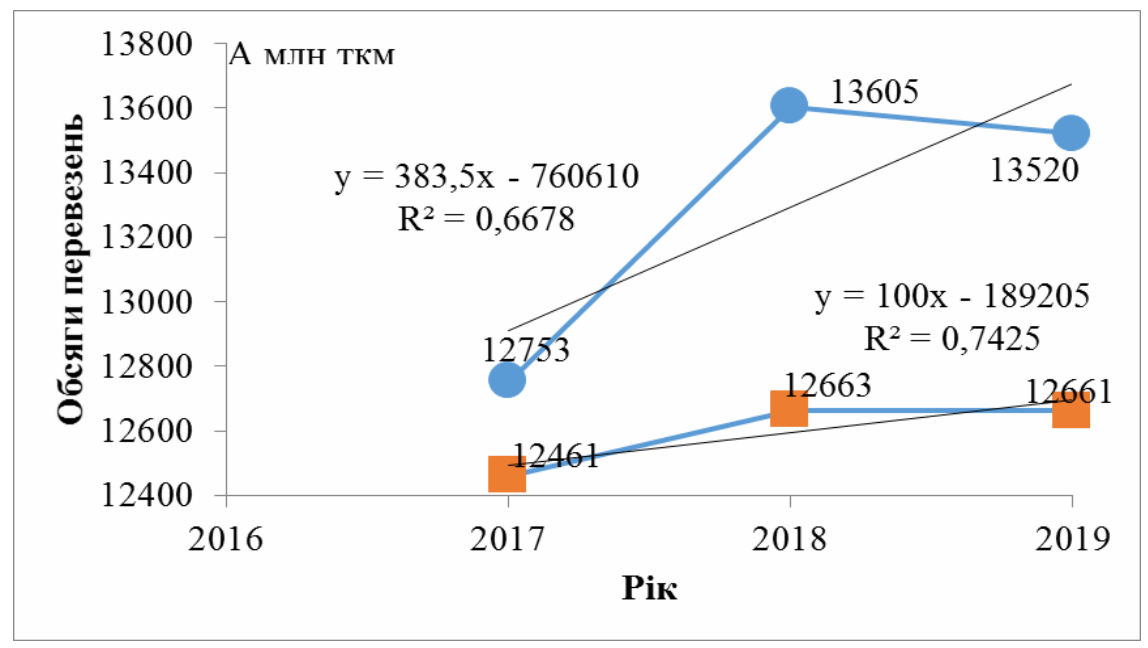

Рис. 1. Динаміка обсягу роботи локомотивів у депо

Це пояснюється як загальною зовнішньополітичною ситуацією, так і зношеністю локомотивного парку, експлуатація якого передбачає як деяке зменшення ваги поїзда, так і зменшення дільничної швидкості. Разом 3 цим як у пасажирському, так i вантажному русі загальний пробіг мав зростання для електровозної тяги (рис. 2) і для тепловозної тяги (рис. 3).

Однак продуктивність локомотивної тяги для електровозів знижувалася (рис. 4).

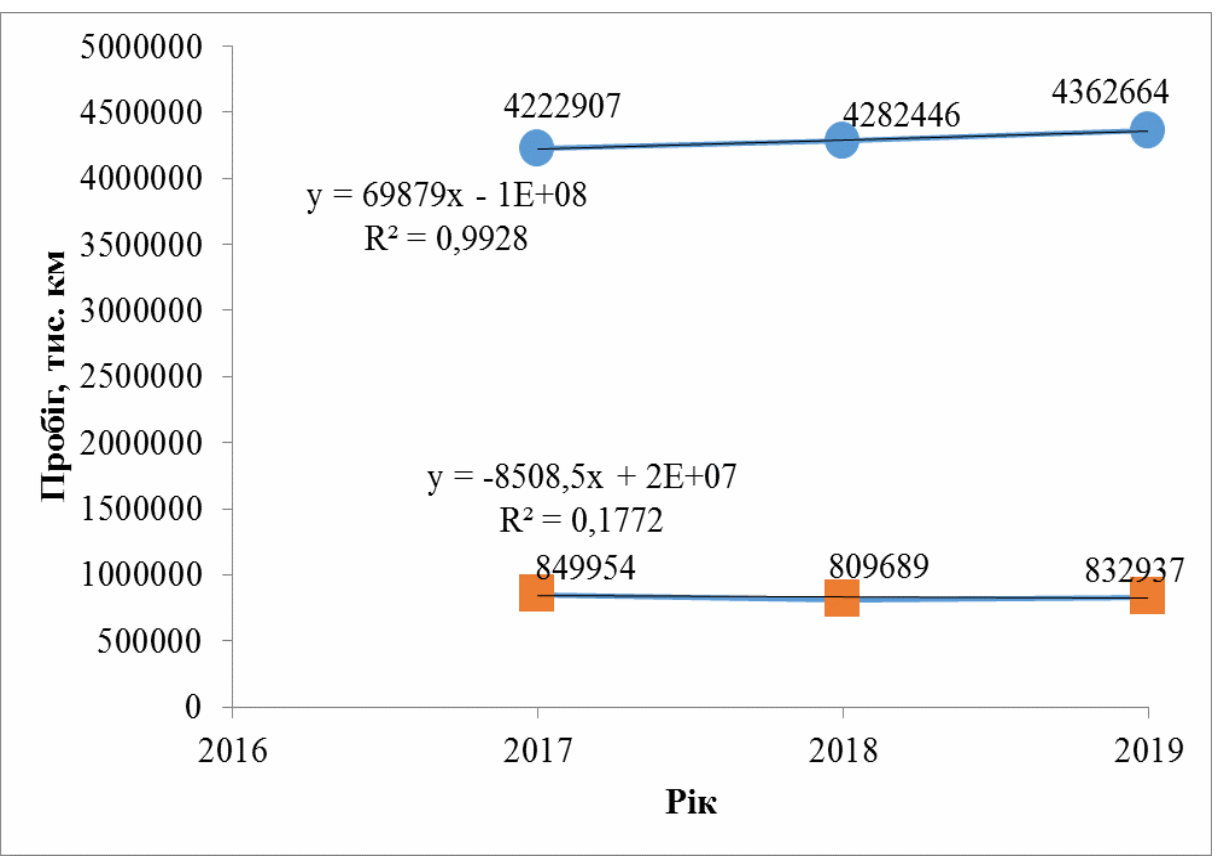

Рис. 2. Динаміка загального пробігу електровозів 


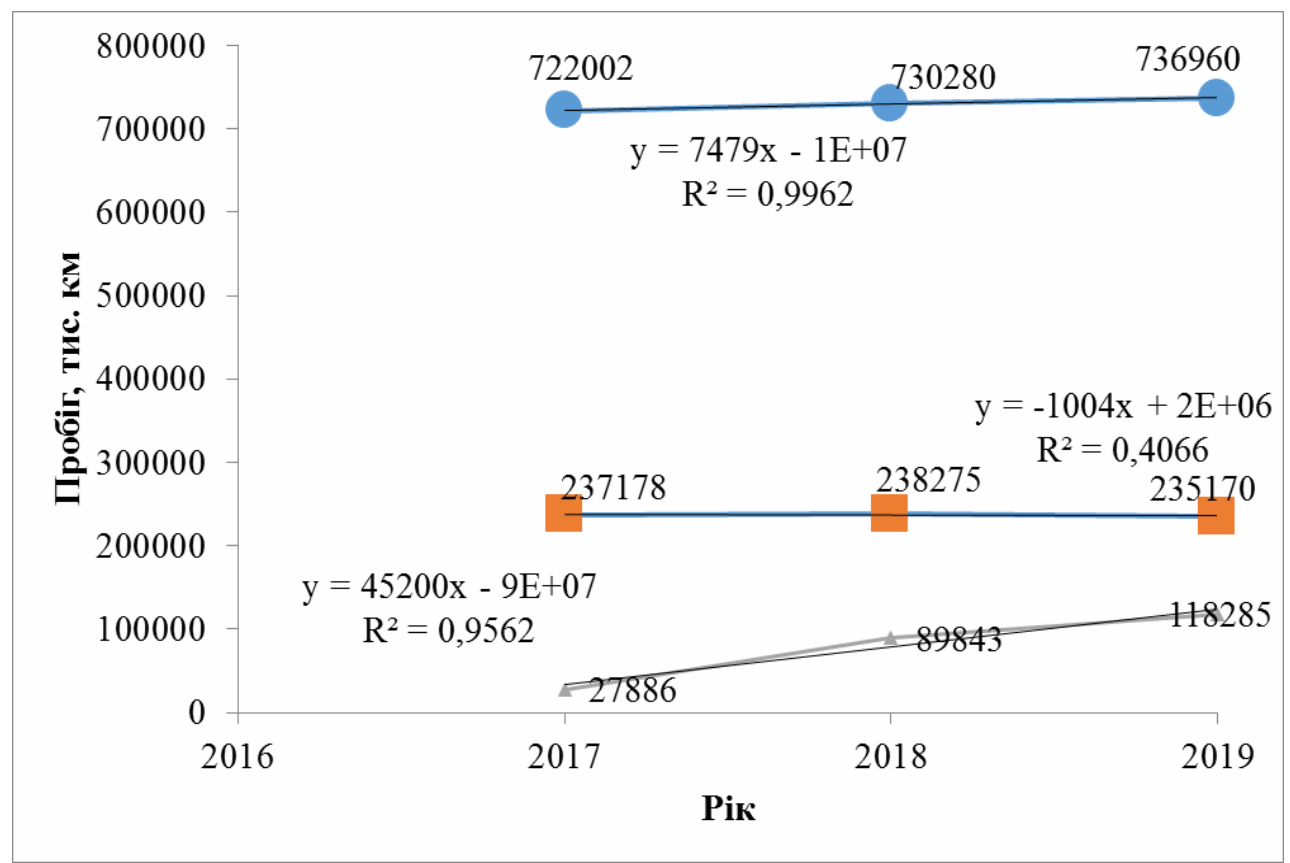

Рис. 3. Динаміка загального пробігу тепловозів

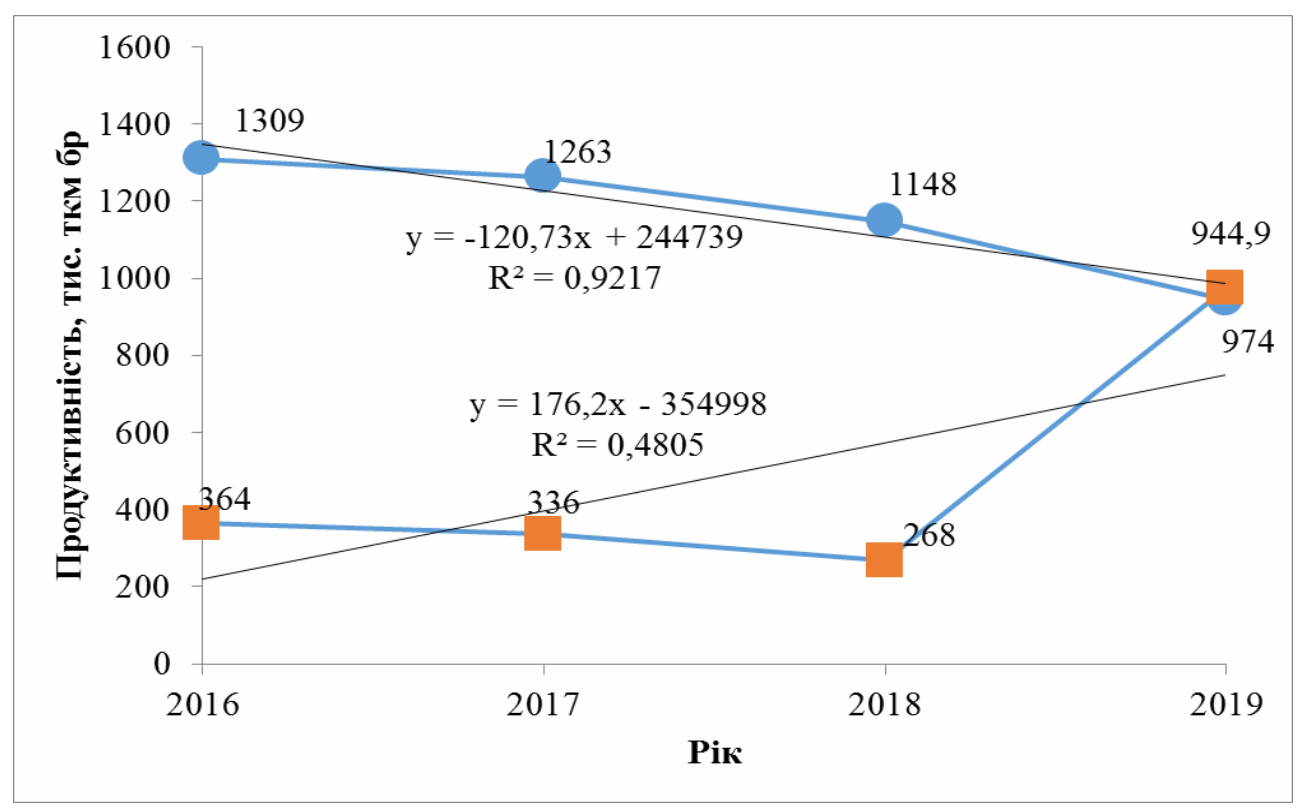

Рис. 4. Зміна продуктивності локомотивів за роками

Причиною цього стало відхилення обсягу планових робіт від фактичних і зменшення середньодобового пробігу. Середня вага поїзда була стабільною (рис. 5).

Середній пробіг на тепловозній тязі збільшився 3 193 км/доб до 690 км/доб, а на електровозній зменшився з 461 км/доб до 332 км/доб (рис. 6).
Незважаючи на зменшення деповського відсотка несправних локомотивів як електровозної, так i тепловозної тяги, він значно перевищує нормативний показник (відповідно 6,4 \% і $8 \%$ ) у середньому у 2-2,5 разу (рис. 7). 


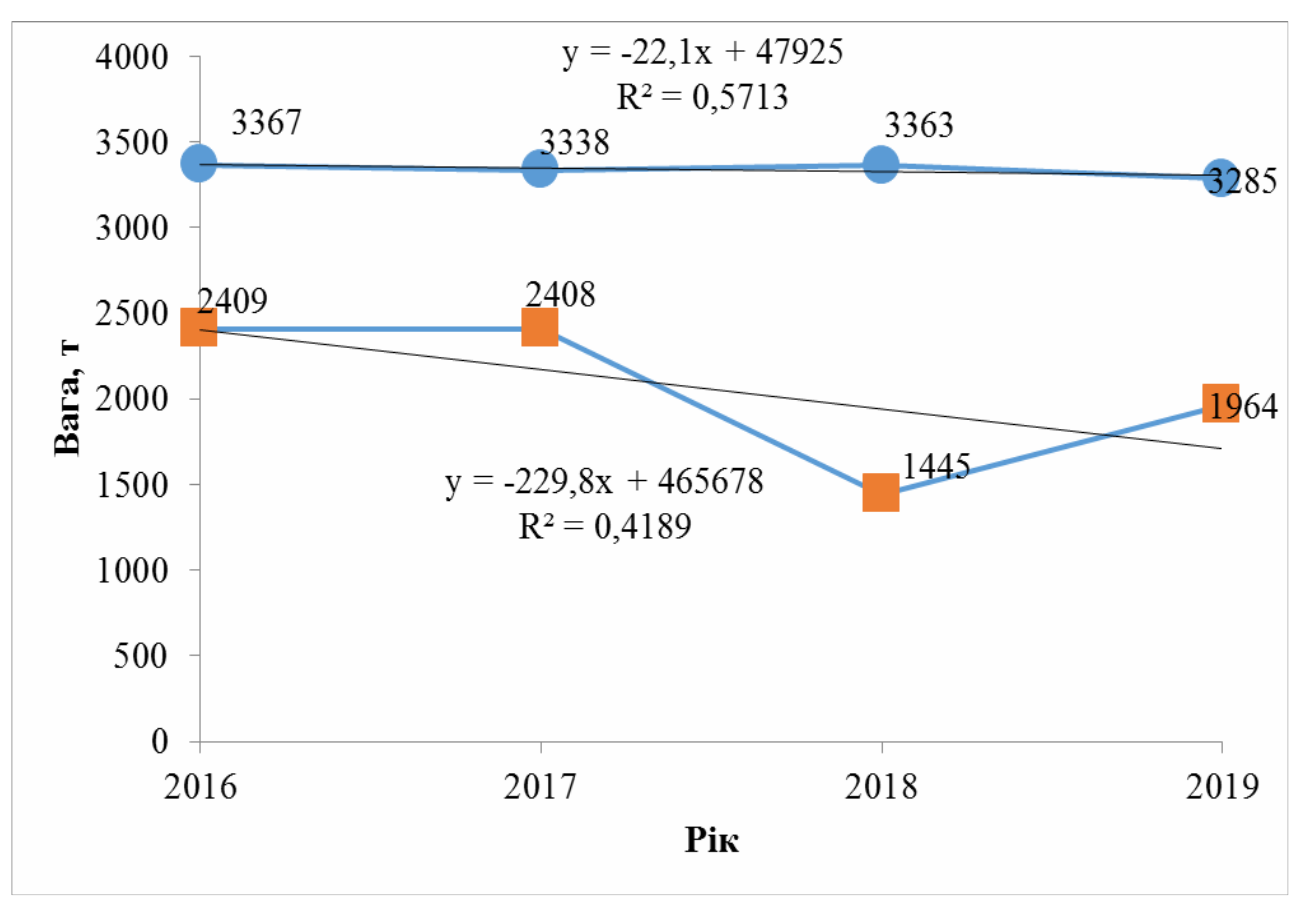

Рис. 5. Середня вага поїзда

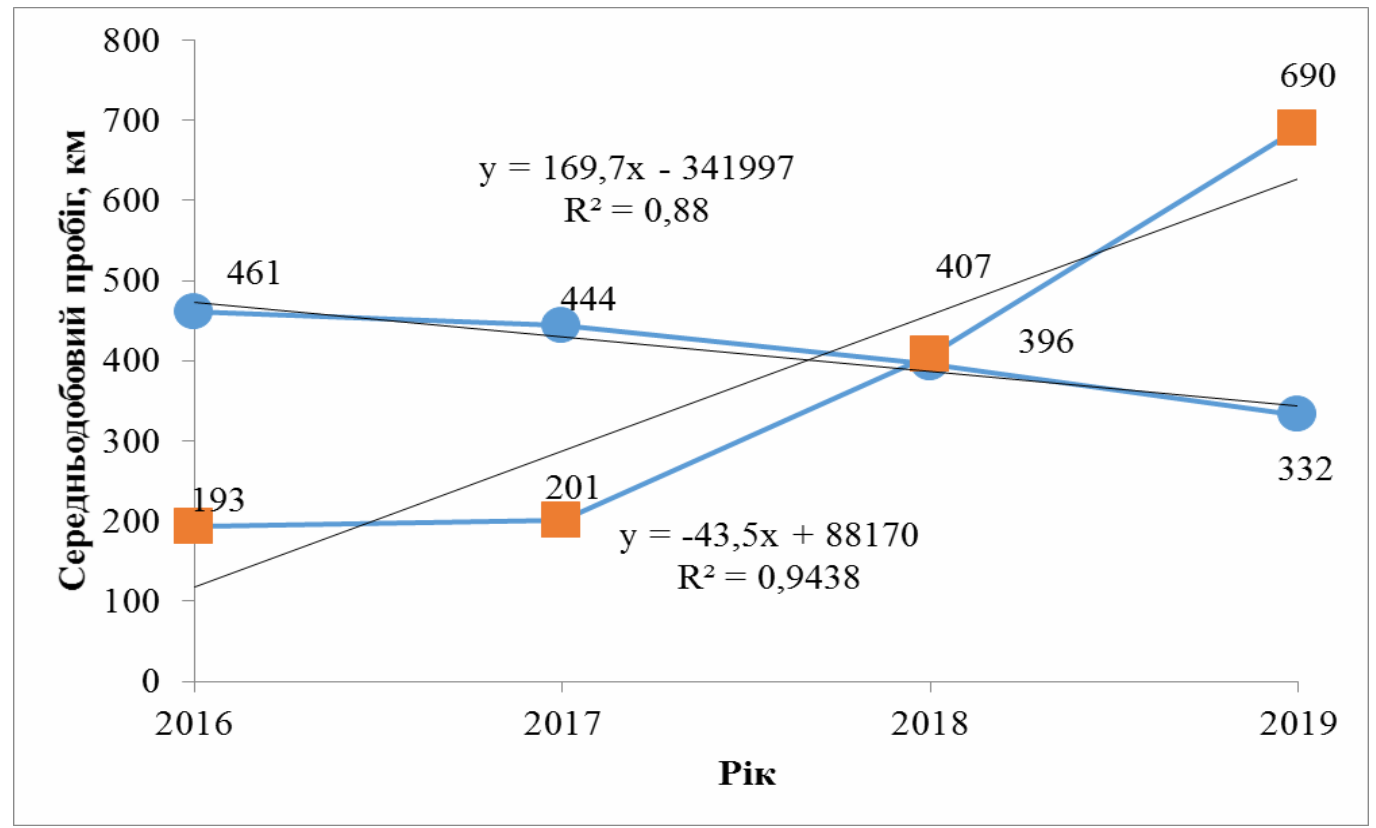

Рис. 6. Середньодобовий пробіг

Зношеність основних фондів, а саме ремонтної інфраструктури, локомотивного парку, втрата зацікавленості молоді до роботи в залізничній галузі і низька кваліфікація персоналу, особливо в ремонті, відсутність контрольно-діагностичного обладнання сприяло такій ситуації.

Середня технічна швидкість по електровозній тязі знизилась майже на 10 км/год з 41,5 км у 2016 році до
33,4 км/год у 2019 році і, навпаки, для тепловозної тяги характерне повільне зростання (рис. 8).

Закриття деяких традиційних маршрутів перевезення і зношеність залізничної інфраструктури призвели до негативних наслідків для електровозної тяги депо, яка є переважною. 


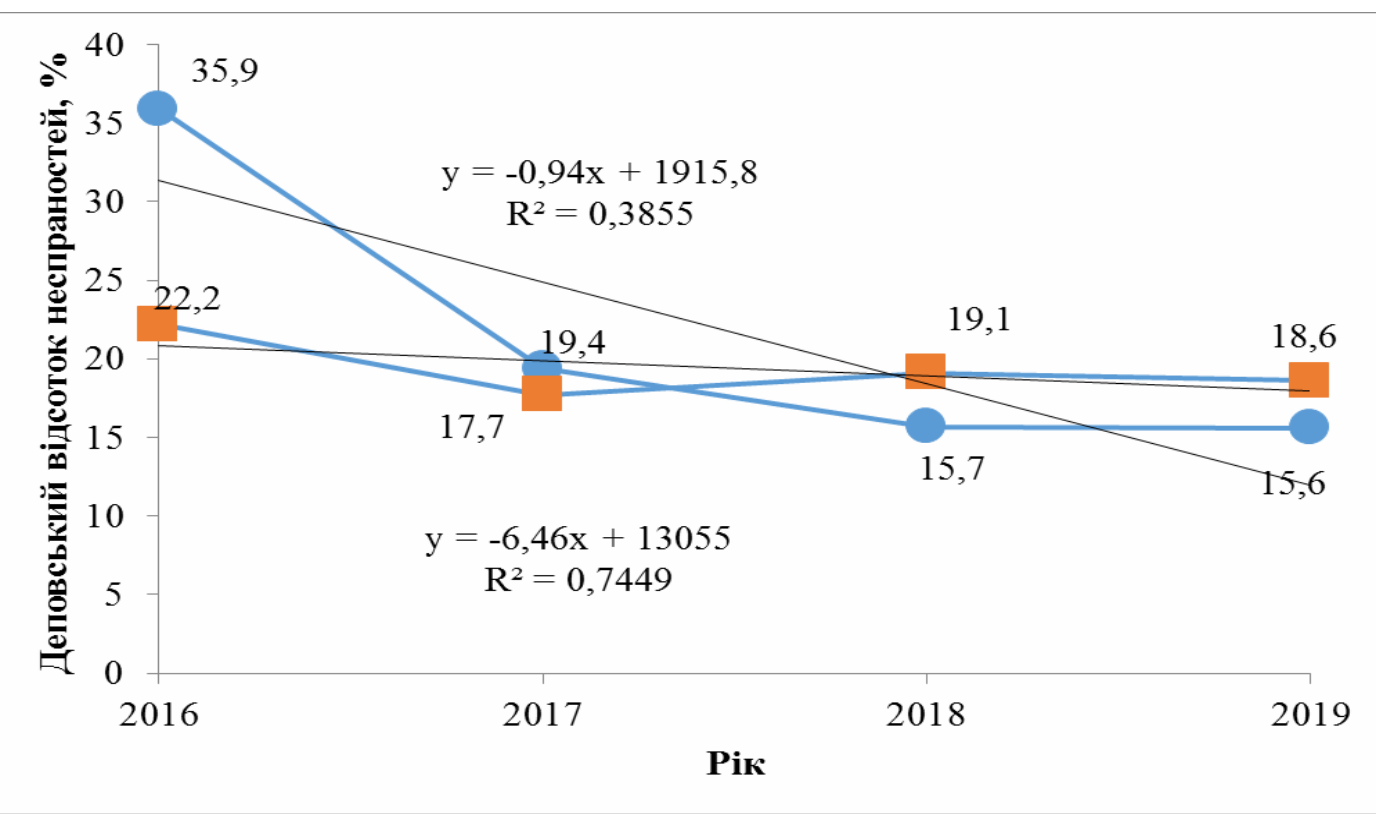

Рис. 7. Деповський відсоток несправностей

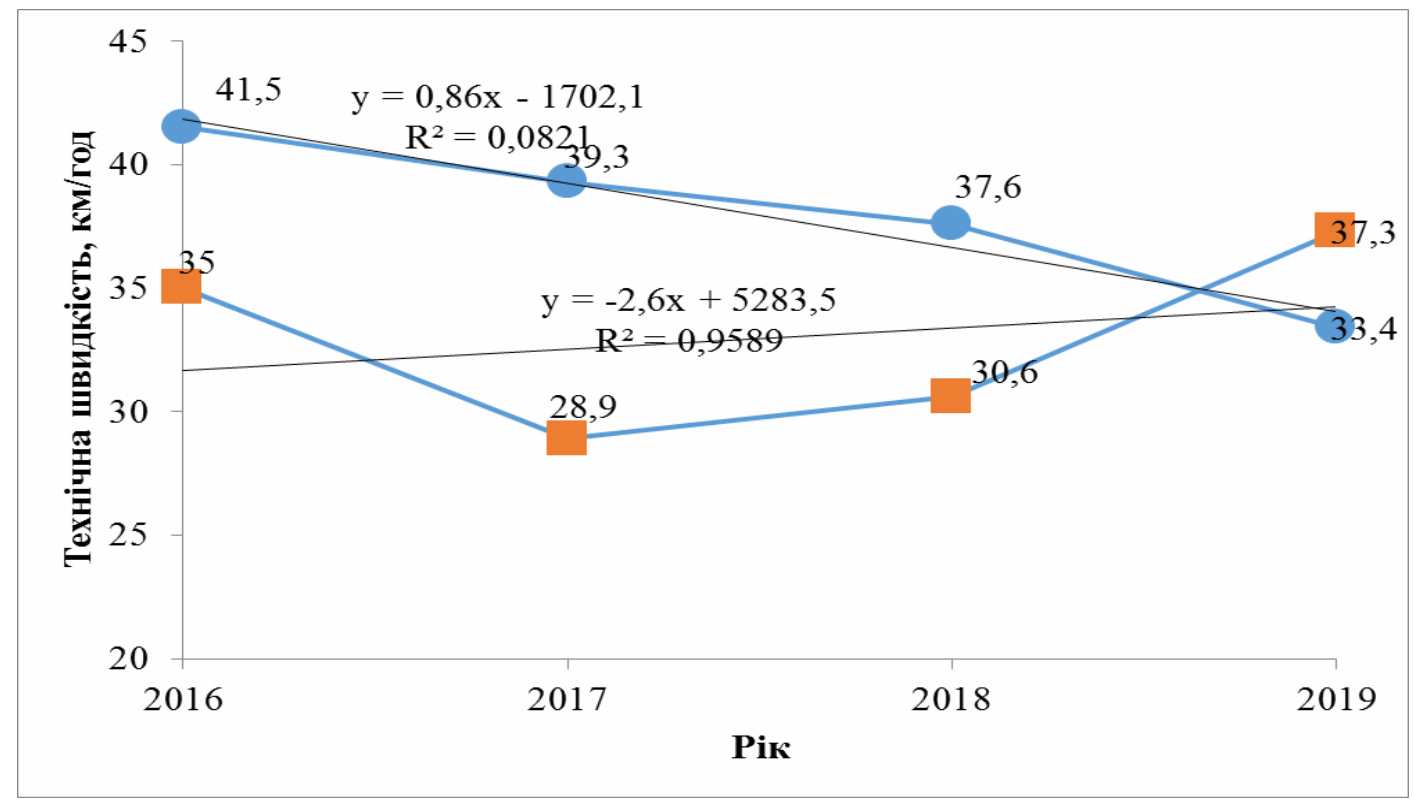

Рис. 8. Технічна швидкість

Скороченням контингенту вдалось підвищити продуктивність праці в депо (рис. 9). Але це має свої межі і наслідки.

Перелічені причини призвели до значного зростання позапланових ремонтів (НР), на які також витрачалися значні ресурси. Так, у 2019 році кількість НР зросла майже у 2,5 разу. У свою чергу неякісне виконання ТО, ПР, наявність НР призводило до перевитрат енергоресурсів в експлуатації (рис. 10-12). 


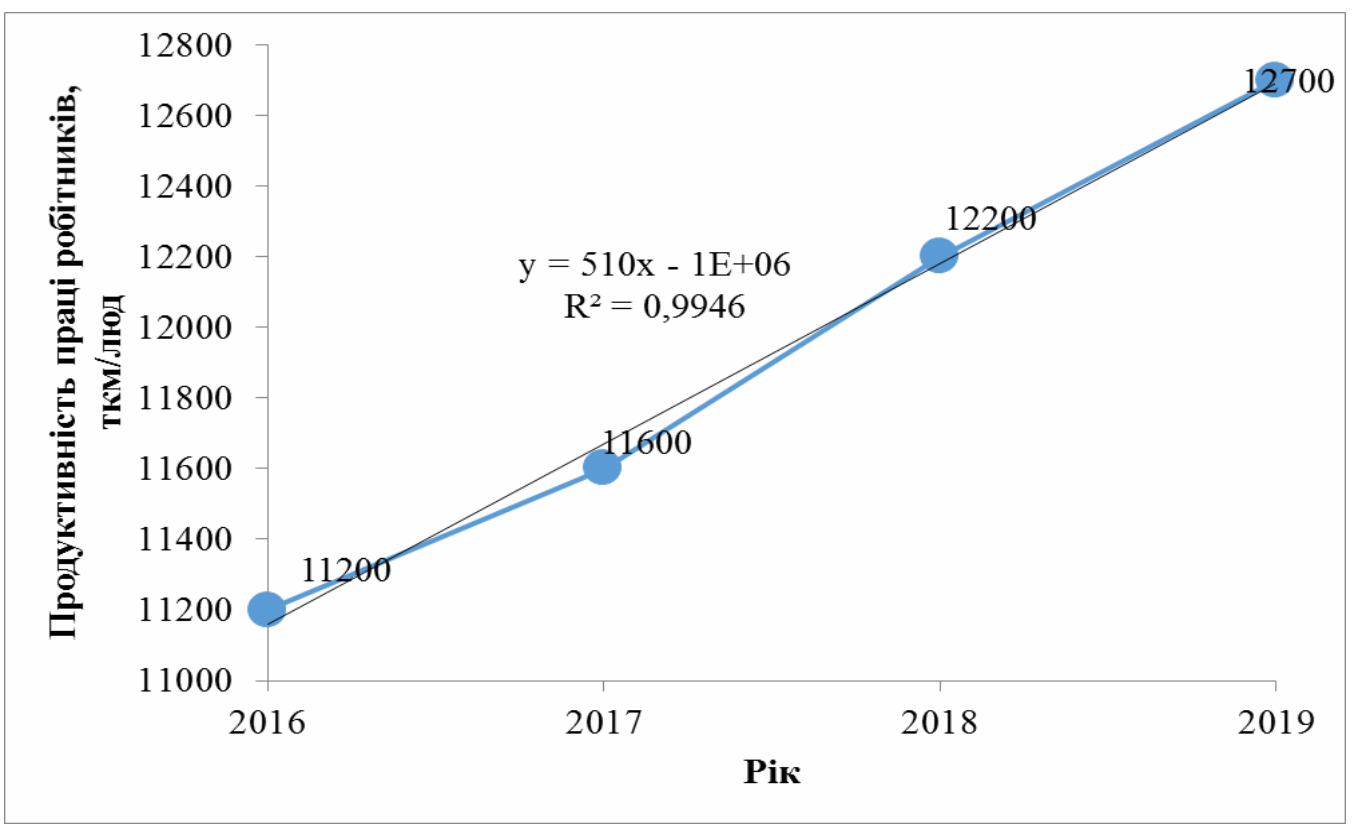

Рис. 9. Продуктивність праці робітників

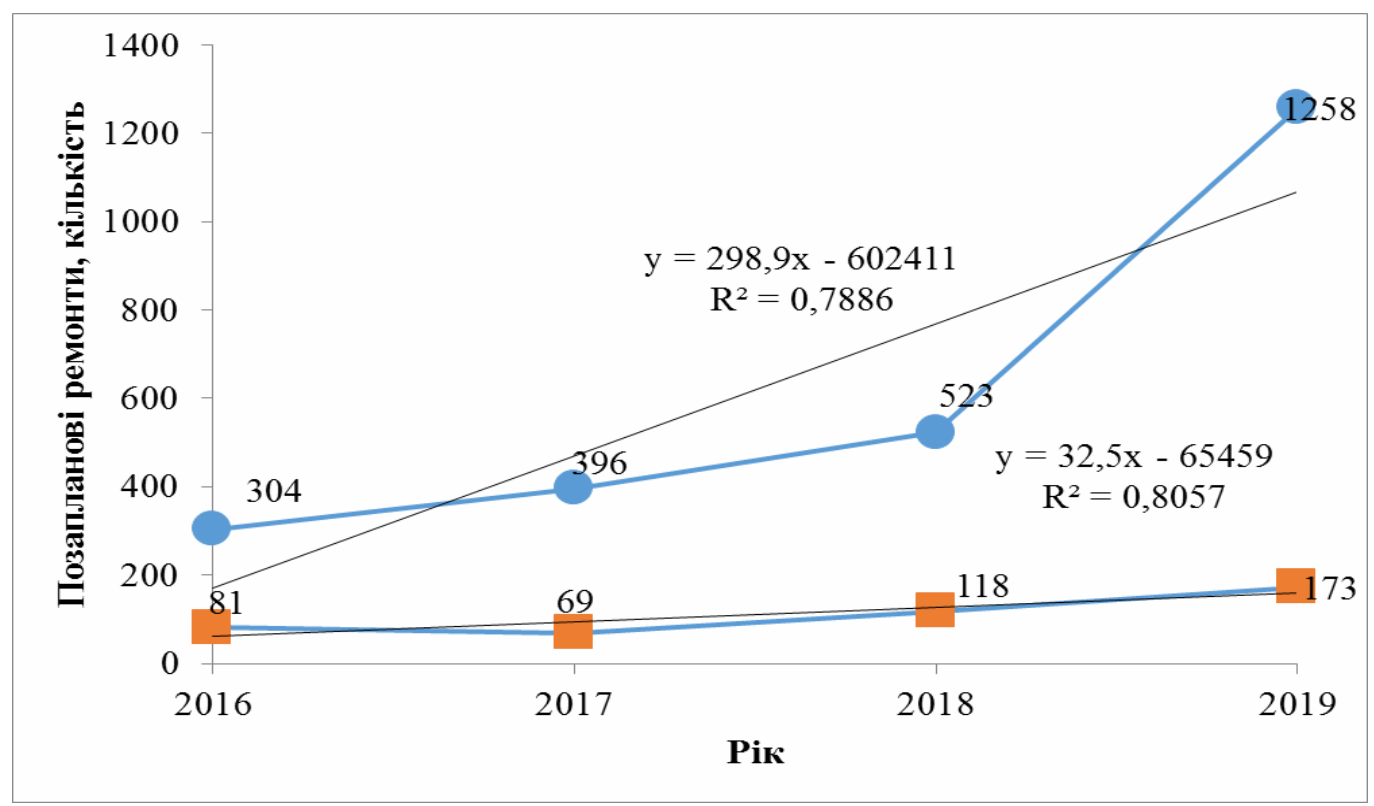

Рис. 10. Динаміка позапланових ремонтів локомотивів у депо (НР) 


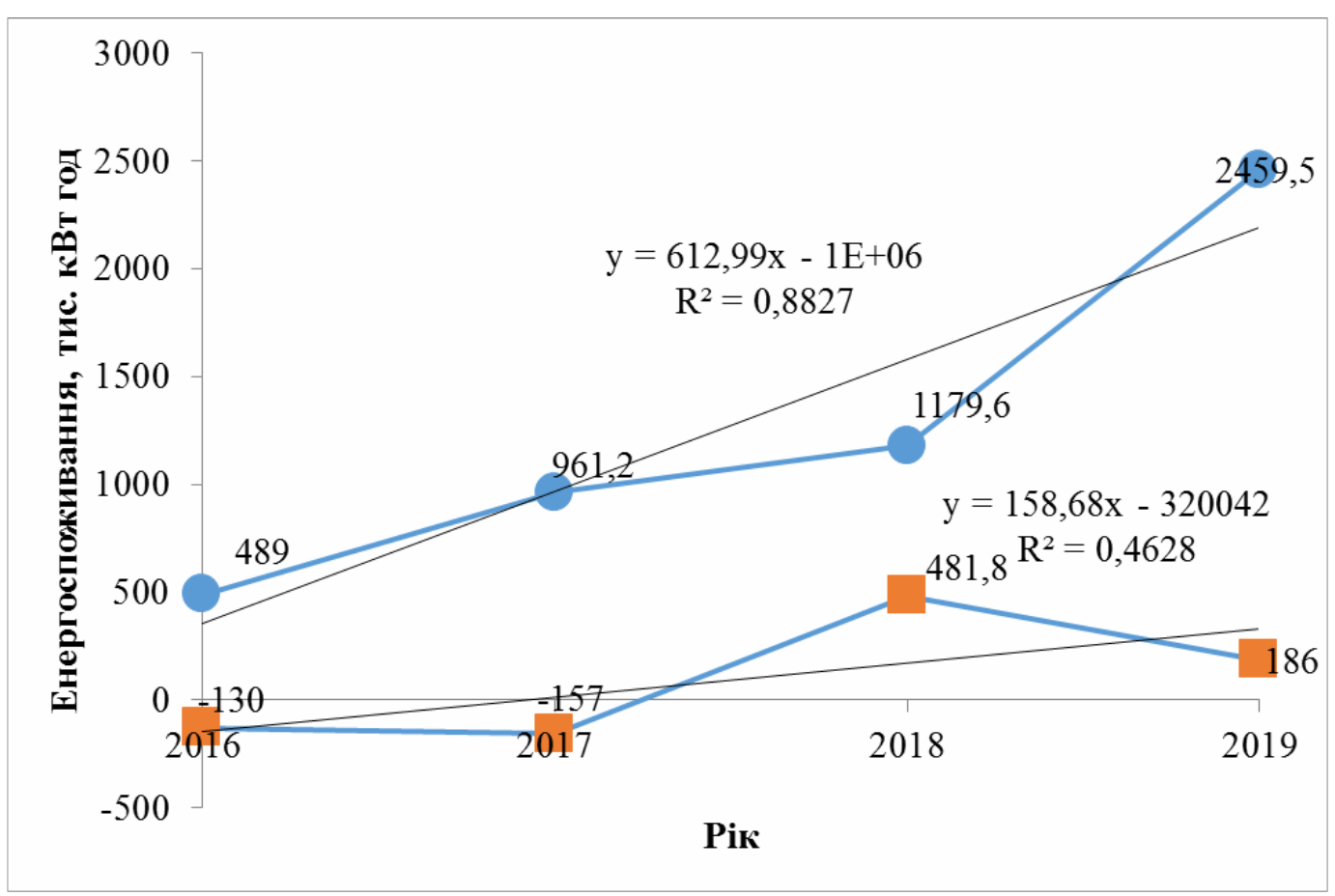

Рис. 11. Економія (-), перевищення (+) енерговитрат (електровози)

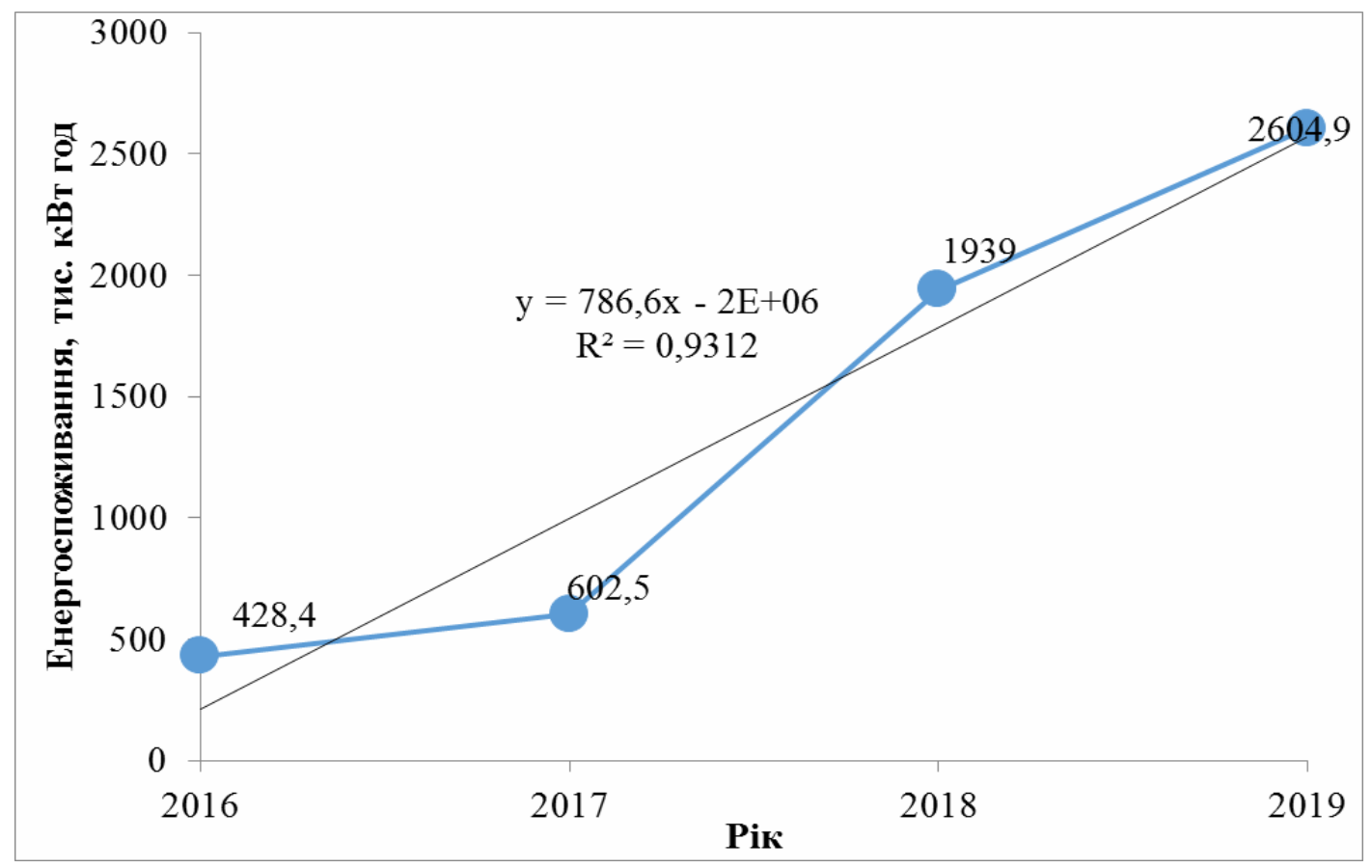

Рис. 12. Економія (-), перевищення (+) енерговитрат (електровози, всього)

А сумарні витрати характеризуються постійним зростанням (рис. 13).

Насторожує велика кількість машиністів, що допускають перевитрати електроенергії (рис.14), палива (рис. 16), та високий рівень витрат палива за роками (рис. 15). 


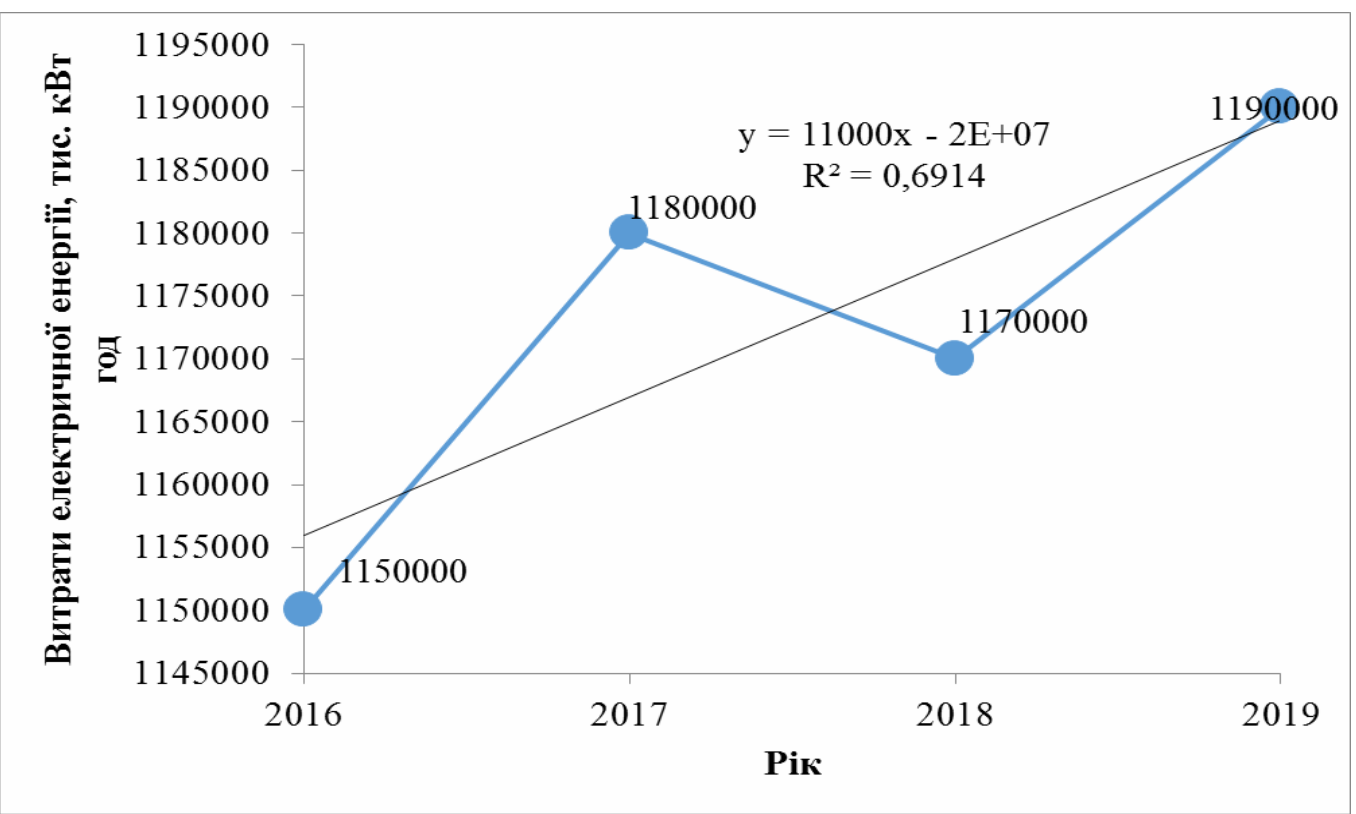

Рис. 13. Динаміка сумарних витрат електроенергії електровозами

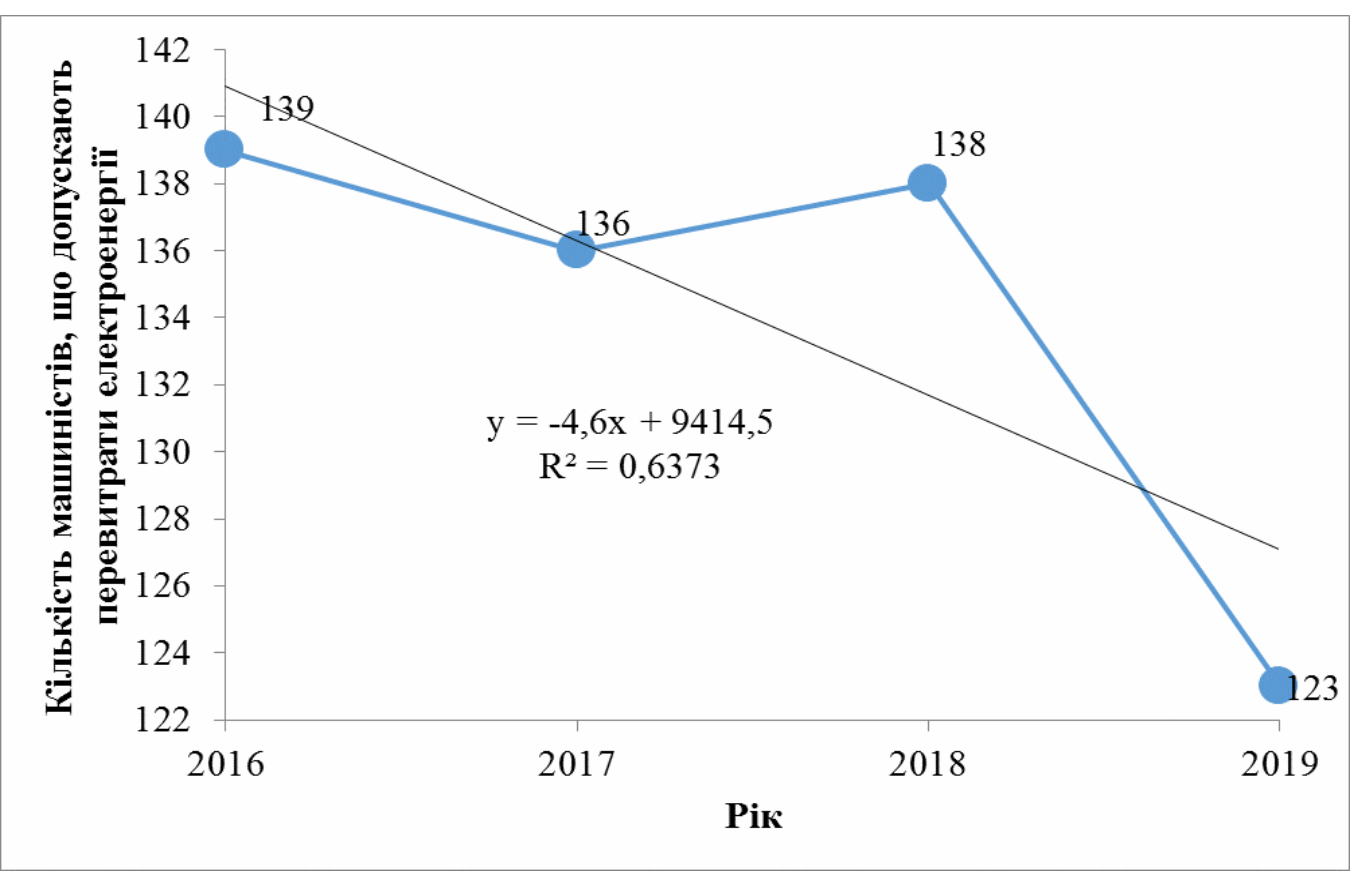

Рис. 14. Кількість машиністів, що допустили перевитрати електроенергії 


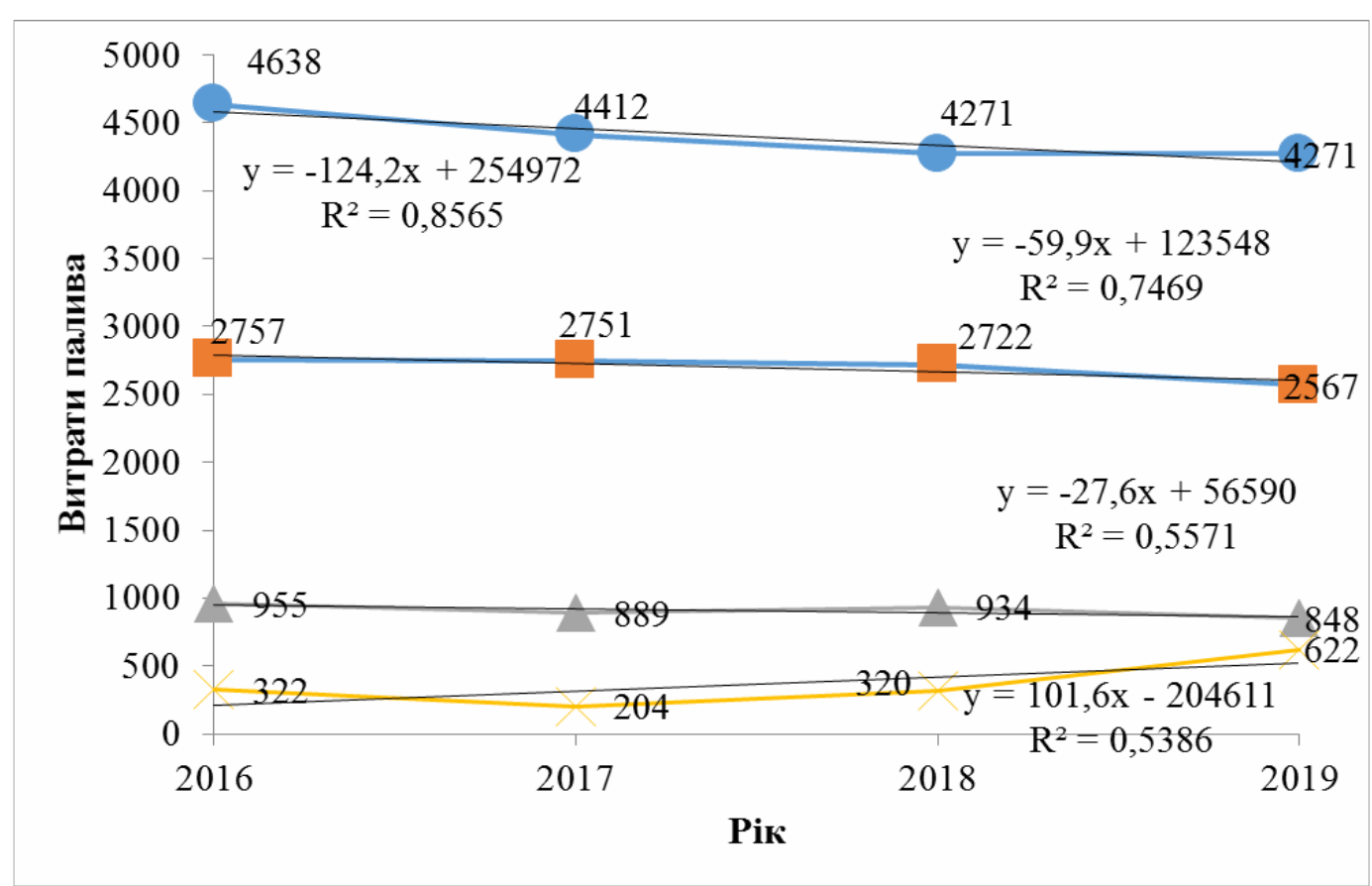

Рис. 15. Динаміка сумарних витрат палива за роками

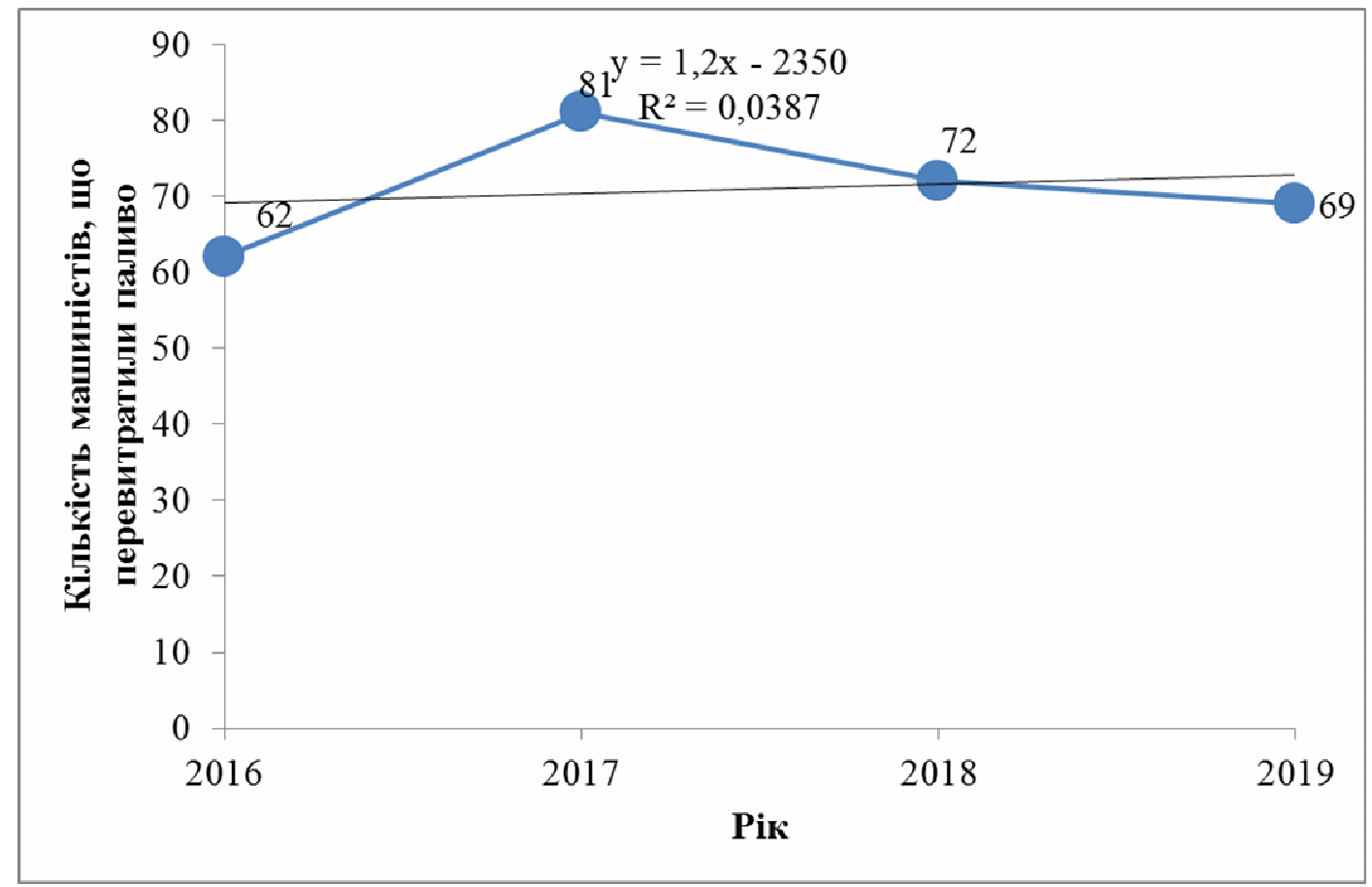

Рис. 16. Кількість машиністів, що перевитратили паливо

Для усунення цих недоліків слід ретельно готувати локомотивні бригади, зокрема організувати підготовку їх на сучасних тренажерах і системах контролю витрат енергоресурсів локомотива.
Відсутність або застарілість сучасного стаціонарного обладнання в ремонті і в експлуатації локомотивів призведе до постійного зростання кількості обточувань колісних пар (рис. 17). 


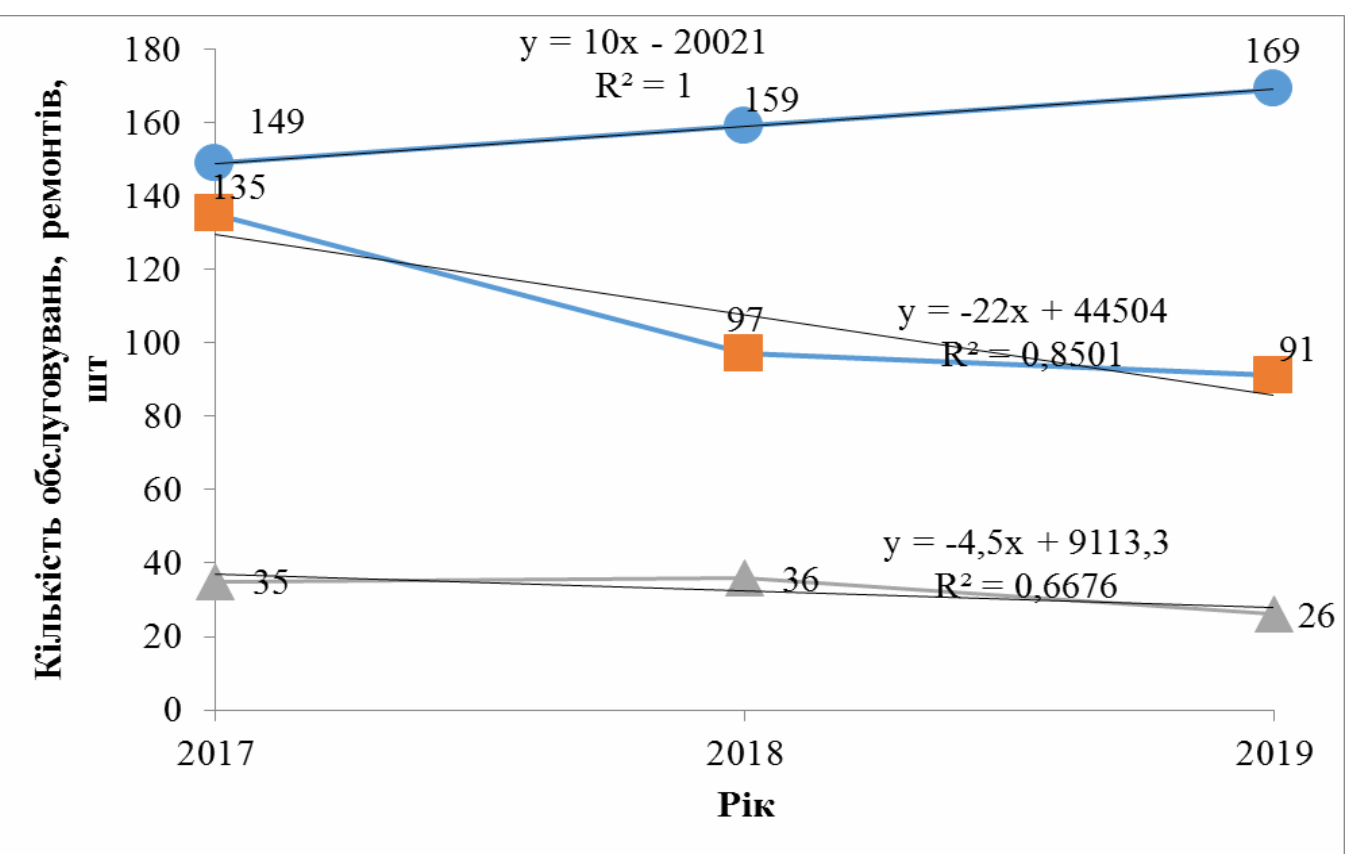

Рис. 17. Динаміка зміни кількості ПР-1, ТО-3, ТО-4 тепловозів за роками

Одночасно збільшується час простою в усіх видах

ТО, ПР (рис. 18) при зменшенні кількості ТО-4 для електровозів (рис. 19) та простоїв на ТО-4 (рис. 20).

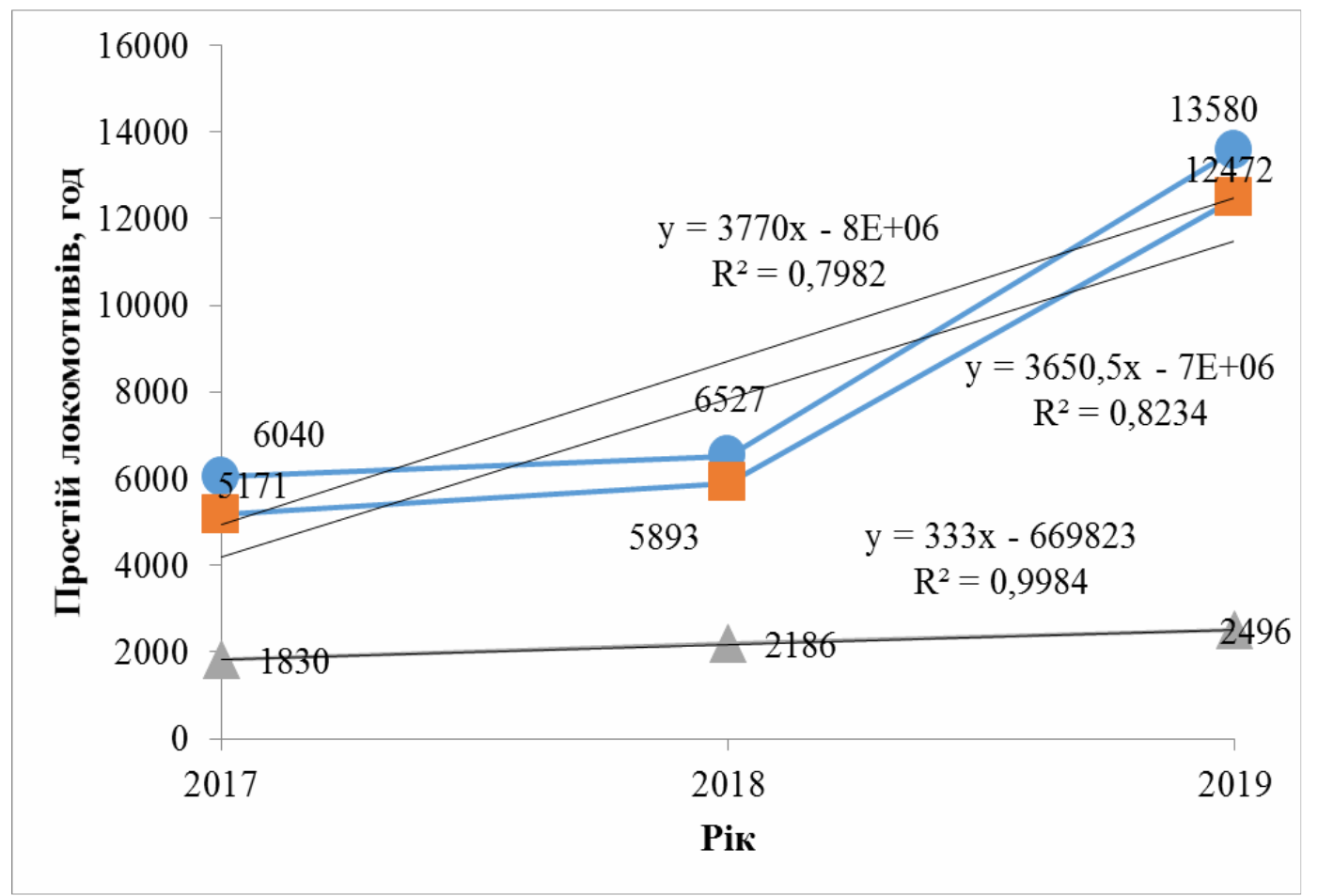

Рис. 18. Динаміка простоїв тепловозів на ПР-1, ТО-3, ТО-4 за роками 


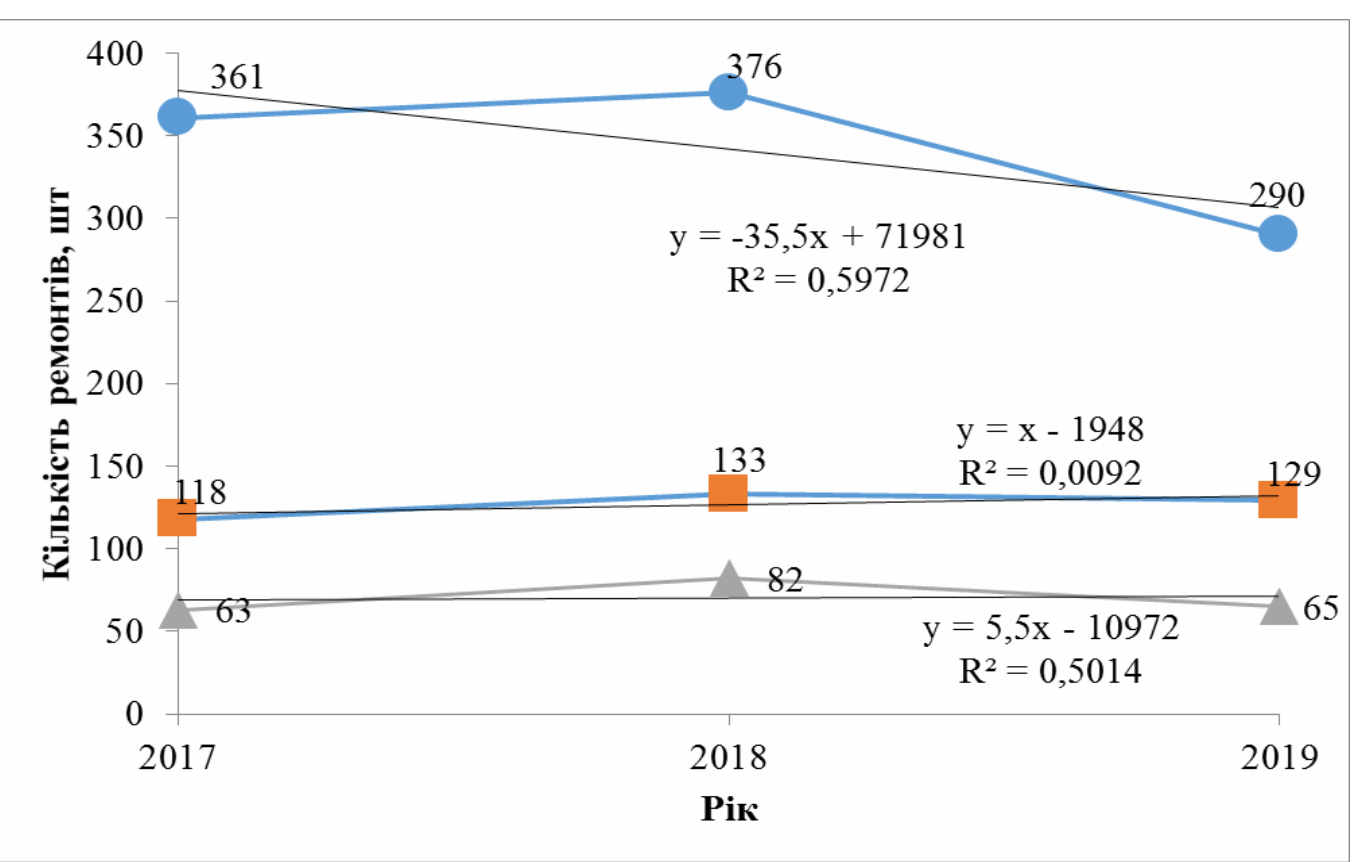

Рис. 19. Динаміка зміни кількості ПР-1, ТО-3, ТО-4 електровозів за роками

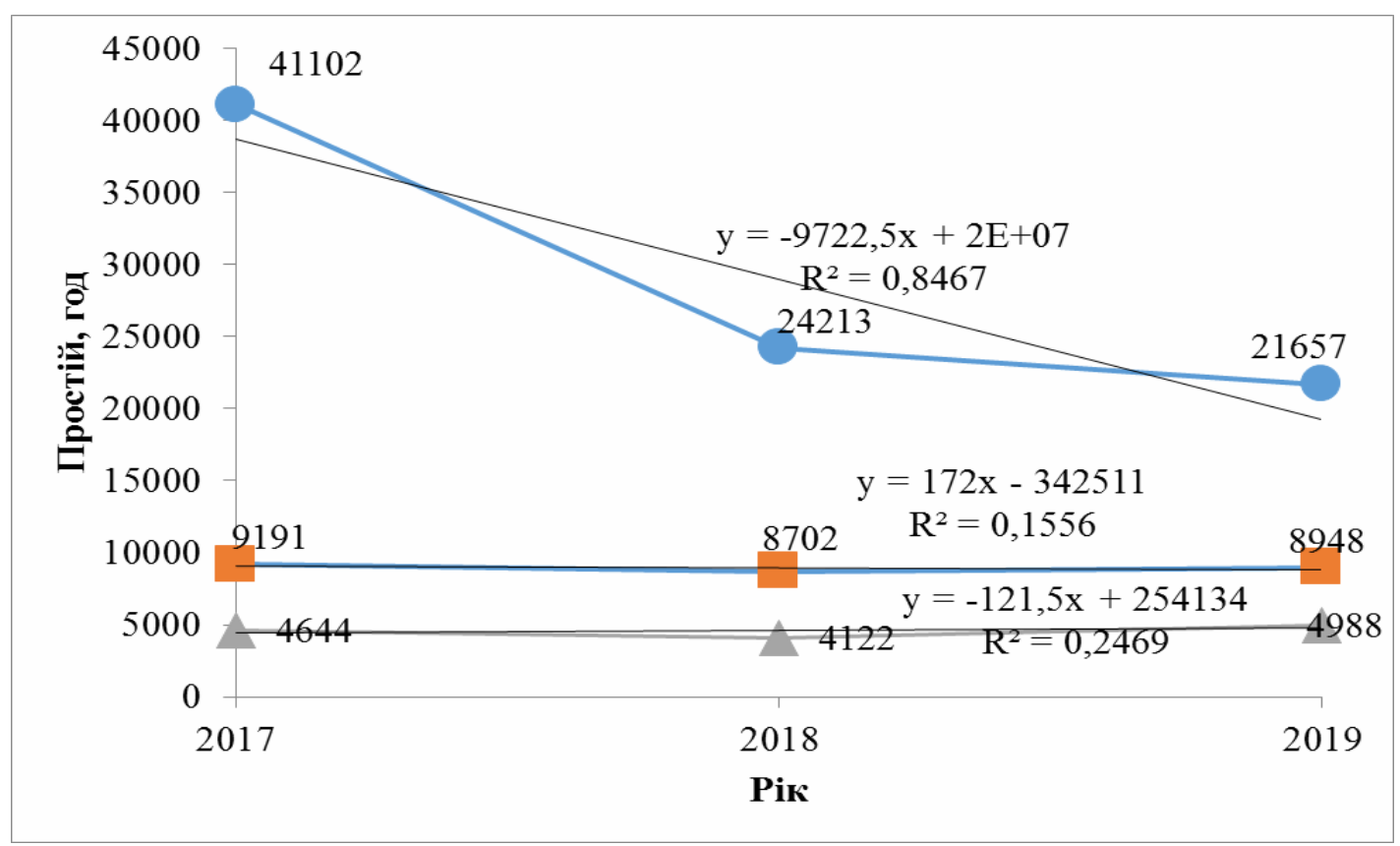

Рис. 20. Динаміка простоїв електровозів на ПР-1, ТО-3, ТО-4

Усе це дає підставу вважати, що економія енергоресурсів у депо має виконуватися комплексно: в експлуатації і в удосконаленні та оновленні ремонтної інфраструктури. Для можливості оцінювання динаміки зміни параметрів і показників роботи локомотивного депо і витрат енергоресурсів на шляху в середовищі Exel визначені математичні залежності цих чинників i перевірка достовірності їх. Відповідні залежності подано на (рис. 1-20).

Одним із напрямів енергозбереження в локомотивному депо є також підвищення ефективності використання енергоресурсів у стаціонарній енергетиці депо на не пов'язані 3 тягою поїздів потреби. 
Зрозуміло, що технічний стан локомотивів неприпустимо поганий, що відображається на витратах енергоресурсів за всіма видами тяги (рис. 11-15).

Зокрема застосування енергоощадних світильників, оптимізація режимів роботи системи освітлення, впровадження світлодіодної техніки, в тому числі заміна ламп розжарювання на компактні люмінесцентні та автоматизація режимів роботи систем освітлення дасть змогу досягти економії електроенергії.

Зменшення теплопровідності i утеплення огороджувальних конструкцій будівель, заміна віконних блоків на склопакети, встановлення газових парогенераторів низького тиску для технологічних потреб, модернізація повітропроводів та компресорного господарства, а також установлення приладів обліку енергоресурсів дасть змогу досягнути суттєвої економії ресурсів.

Для продовження цілеспрямованої роботи зі зниження витрат паливно-енергетичних ресурсів на інші потреби, що не пов'язані 3 тягою поїздів, доцільно запровадити певні заходи.

Скорочення витрат дизельного пального на прогрів тепловозів в очікуванні ремонту та технічного обслуговування за рахунок використання теплих стійл, дотримання режимів прогріву тепловозів, розхолоджування локомотивів після тривалого простою. Для цього необхідно організувати на зимовий період відстою в очікуванні ремонту максимальної кількості тепловозів у приміщеннях 3 опаленням, установити контроль над режимом прогріву дизеля залежно від температури навколишнього середовища, підвищити якість керування парком локомотивів, дотримуватися графіка постановки тепловозів на ремонт, зменшити час очікування до постановки в цех.

Зниження витрат дизельного пального на проведення реостатних випробувань завдяки підвищенню якості ремонту та зменшенню випадків проведення повторних реостатних випробувань. Виключення руху локомотивів на реостатні випробування своїм ходом (доки тепловоз не відрегульований і має підвищені витрати палива).

Поліпшення природної освітленості робочих місць (своєчасне очищення світлоаероційних ліхтарів у покрівлі будівель, розташування робочих місць по можливості максимально близько до віконних прорізів, використання світловідбивних систем для максимального розсіювання сонячних променів у день та забезпечення відображення світла ламп у вечірній час).

Підсилення контролю відповідальних керівників депо за відключення електроенергії на дільницях, не затребуваних у виробничому процесі, переведення схем включення/відключення електричної енергії на максимально економічні, відключення вентиляції в робочий час, виключення витоків стисненого повітря в пневмоустановках та повітропроводах, проведення комісійних перевірок для визначення нераціонального використання електроенергії з відшкодуванням збитків (причетними працівниками) при нецільовому використанні енергоресурсів, контроль споживання по дільницях, залучення в процес економії витрат усього персоналу.

\section{Висновки}

За результатами проведених досліджень зроблено такі висновки:

1. Виконаний аналіз динаміки показників роботи локомотивів у депо щодо витрат енергоресурсів показав, що на фоні погіршення технічного стану локомотивного парку i ремонтної інфраструктури, майже усі чинники мають негативну динаміку.

2. Для можливості моделювання запровадження необхідних організаційних, економічних і технічних заходів визначено математичні залежності динаміки зміни характеристик (параметрів) роботи локомотивного депо К.

3. Показано, що вирішення завдання підвищення i стабілізації енергоефективності депо необхідно виконувати комплексно як в експлуатації, так і в ремонті. Для цього депо необхідно оснастити сучасними контрольно-вимірювальними засобами витрат енергоресурсів, запровадити контроль і оцінку професійних навичок локомотивних бригад за допомогою тренажерів. У ремонтне господарство запроваджувати сучасне ремонтне i діагностичне обладнання.

\section{Список використаних джерел}

1. Puzyr V. G., Krasheninin O. S., Zhalkin D. S., Datsun Y. M., Obozny O. M. Estimation of the influence of the interaction of factors pairs on the coefficient of route execution possibility. IOP Conf. Series: Materials Science and Engineering, № 659, 2019 (Scopus)

2. Сергієнко М. I. Основні напрямки роботи Укрзалізниці з енергозбереження та іiі результати. Локомотив-інформ. 2010. № 4. С. 24-26.

3. Кумайгородская Н. Энергосбережение: трудимся на опережение. Магістраль. 2012. № 79 (1765). C. $4-5$.

4. Про енергозбереження: Закон України від 01.07.1994. Веб-сайт «Законодавство України». URL:

http://zakon2.rada.gov.ua/laws/show/про\%20енерго3 береження (lastaccess: 15.01.2021).

5. Энергетически оптимальное управление транспортными системами: Пер. с чешск. / Л. Скива, Я. Яначек, П. Ценек. Москва: Транспорт, 1992. $247 \mathrm{c}$. 
6. Рекомендації 3 організації ресурсозберігаючих заходів на об'єктах локомотивного господарства Укрзалізниці: ЦТ-0202: Затв. Наказом Укрзалізниці від 24.12.2010 № 215-ЦЗ. Київ, 2011. $88 \mathrm{c}$.

7. Мугинштейн Л. А., Виноградов С. А., Ябко И. Я. Энергооптимальный тяговый расчет движения поездов. Железнодорожный транспорт. 2010. № 2. С. 24-29.

8. Галиев И. И., Нехаев В. А. Оптимизация ведения поезда. Железнодорожный транспорт. 2000. № 10. С. 41-42.

9. Костромин А. М. Оптимизация управления локомотивом. Москва: Транспорт, 1979. 119 с.

10. Выбор энергетически оптимальных режимов ведения поездов / Е. П. Блохин, А. Н. Пшинько, Г. В. Евдомаха, В. В. Скалозуб, В. Б. Землянов. Залізничний транспорт України. 2001. № 6. C. 19-22.

11. Щербаков О.О. Дослідження тягових властивостей електровозів 2ЕЛ5 на базі вагоналабораторії. 3б. наук. праць Укр. держ. акад. залізнич. трансn. Харків: УкрДАЗТ, 2009. Вип. 108. С.194-197.

12. Тягово-энергетическая лаборатория для испытания локомотивов: офіційний сайт Ростовського державного університету шляхів сполучення.

URL: http://www.rgups.ru/pages.php?id=4009 (lastaccess: 05.01.2021)

13. Методика проведення енергетичного аудиту локомотивного депо: затв. Наказом Укрзалізниці від 02.06.2006 № 419-ЦЗ.Київ, 2006. 160 с.

14. Блохин Е. П., Пшинько А. Н., Скалозуб В. В. Проблемы вождения поездов в условиях оптового рынка электроэнергии. Залізничний транспорт Украӥни. 2009. № 6. С. 10-15.

15. Ларин Р. М., Плясунов А. В., Пяткин А. В. Методы оптимизации. Примеры и задачи: учеб. пособ. Новосибирск : Новосиб. ун-т, 2003. 115 с.

16. Беллман Р., Дрейфус С. Прикладные задачи динамического программирования. Москва: Наука, 1965. 460 с.

A. Krasheninin, M. Odiehov, M. Berezniak, D. Pyvovar. Proposals for reducing energy costs in locomotive depo.

Abstract. The locomotive industry of the railways is a significant consumer of fuel and energy resources. Energy costs make up a significant part of Ukrzaliznytsia's operating costs, up to $20 \%$. Of these, more than $80 \%$ of diesel fuel and $83 \%$ of electricity is consumed by locomotives to ensure the transportation process. Naturally, this is the basis for solving the problem of reducing the energy consumption of the railway. However, the general wear of rolling stock, including the locomotive fleet, causes the deterioration of the main performance of railway transport and performance of the locomotive depo. In the current conditions in the depot, it is necessary to follow the strategy of introducing a comprehensive approach to change the situation for the better: in the operation of the locomotive fleet, in repair, in economic activity, in the system of advanced training of locomotive crews and repair personnel. An important component of this process is the introduction of maintenance, locomotives of modern diagnostic equipment for quality assessment of the technical condition of units and systems of locomotives. The energy economy of the locomotive depot occupies a significant share of the costs of organizing the operation of other facilities of the depot and locomotive fleet. In the conditions of rise in prices for energy resources before locomotive economy urgent tasks on development of strategy of economy of energy consumption are actual. The article analyzes the technical condition of the locomotive fleet and the dynamics of energy consumption of the depot over several years. With this in mind, specific measures are planned for economic energy consumption in the locomotive depo.

Keywords: locomotive economy, energy consumption, energy saving.

Надійшла 23.04.2021 p.

Крашенінін Олександр Семенович, д-р техн. наук, професор кафедри експлуатації та ремонту рухомого складу Украӥнського державного університету залізничного транспорту. ORCID iD: 0000-0001-74623372.E-mail: krasheninin@kart.edu.ua.

Одєгов Микола Миколайович, старший викладач кафедри електроенергетики, електротехніки та електромеханіки Українського державного університету залізничного транспорту. ORCID iD: 0000-0003-3967-9009. E-mail: odegov@kart.edu.ua.

Березняк Максим Констянтинович, магістр, група 212-ЛЛГ-319 Українського державного університету залізничного транспорту.

Пивовар Дмитро Іванович, магістр, група 211-ЛЛГД19 Українського державного університету залізничного транспорту.

A. Krasheninin, Dr. Sc. (Tech.) professor, department of maintenance and repair of rolling stock, Ukrainian State University of Railway Transport. ORCID iD: 0000-00017462-3372. E-mail: krasheninin@kart.edu.ua.

M. Odiehov, Senior Lecturer, department of electric power, electrical engineering and electromechanics, Ukrainian State University of Railway Transport. ORCID iD: 0000-0003-3967-9009. E-mail: odegov@kart.edu.ua.

M. Berezniak, master, Group 212-ЛЛГ-319, Ukrainian State University of Railway Transport.

D. Pyvovar, master, Group 211-ЛЛГ-319, Ukrainian State University of Railway Transport. 